ISSN: 2302-8556

E-Jurnal Akuntansi Universitas Udayana

Vol.25.3.Desember (2018): 1884 - 1912

DOI: https://doi.org/10.24843/EJA.2018.v25.i03.p10

\title{
Pengaruh Proporsi Komisaris Independen, Leverage, Sales Growth, Dan Profitabilitas Pada Tax Avoidance
}

\author{
Ni Putu Winda Ayuningtyas ${ }^{1}$ \\ I Ketut Sujana ${ }^{2}$
}

${ }^{1}$ Fakultas Ekonomi dan Bisnis Universitas Udayana (Unud), Bali, Indonesia
email: windaayuningtyas70@ yahoo.com/ Telp: 085739090736
${ }^{2}$ Fakultas Ekonomi dan Bisnis Universitas Udayana (Unud), Bali, Indonesia

\begin{abstract}
ABSTRAK
Penelitian ini bertujuan untuk meneliti variabel proporsi komisaris independen, leverage, sales growth dan profitabilitas yang mempengaruhi perusahaan melakukan tax avoidance. Penelitian ini dilakukan pada seluruh perusahaan manufaktur yang terdaftar di Bursa Efek Indonesia (BEI) tahun 2014-2017, dengan jumlah pengamatan sebanyak 200 sampel. Pemilihan sampel menggunakan teknik probability sampling yaitu teknik purposive sampling. Teknik analisis data yang digunakan adalah uji analisis regresi linier berganda.Hasil penelitian menunjukkan bahwa proporsi komisaris independen tidak berpengaruh pada tindakan tax avoidance, leverage berpengaruh positif pada tindakan tax avoidance, sedangkan sales growth dan profitabilitas berpengaruh negatif pada tindakan tax avoidance.
\end{abstract}

Kata kunci:tax, leverage, sales growth, profitabilitas

\begin{abstract}
This study aims to examine the variables of the proportion of independent commissioners, leverage, sales growth and profitability that affect companies doing tax avoidance. This research was conducted on all manufacturing companies listed on the Indonesia Stock Exchange (IDX) in 2014-2017, with a total of 200 samples. The selection of samples using probability sampling technique is purposive sampling technique. The data analysis technique used is a multiple linear regression analysis. The results of the study show that the proportion of independent commissioners has no effect on tax avoidance actions, leverage has a positive effect on tax avoidance actions, while sales growth and profitability have a negative effect on tax avoidance actions.

Keywords: tax, leverage, sales growth, profitability
\end{abstract}


Ni Putu Winda Ayuningtyas dan I Ketut Sujana. Pengaruh...

\section{PENDAHULUAN}

Pajak merupakan salah satu sumber pendapatan negara yang sangat besar. Manfaat pajak sangat besar sekali untuk meningkatkan kesejahteraan masyarakat dan kegiatan pembangunan nasional negara Indonesia, oleh karena itu pemungutan pajak dapat dipaksakan berdasarkan Undang-Undang Perpajakan yang berlaku di Indonesia. Besarnya manfaat pajak untuk pembangunan nasional mendorong pemerintah untuk terus memaksimalkan pendapatan negara dengan terus melakukan evaluasi dan pemeriksaan terhadap wajib pajak khususnya WP Badan atau perusahaan karena perusahaan terutama perusahaan manufaktur berpotensi besar menyumbangkan pajak penghasilannya setiap tahun kepada negara. Setiap Wajib Pajak diwajibkan untuk membayar iuran pajak kepada Negara, tetapi bagi perusahaanpajak merupakan beban karena dapat mengurangi laba bersih perusahaan, terlebih lagi tidak mendapatkan imbalan langsung ketika membayar pajak. Oleh karena itu, hampir sebagian besar perusahaan tidak ada yang sukarela membayar pajak. Perusahaan membayar pajak karena sifatnya memaksa, apabila perusahaan tidak membayar akan terkena sanksi dan denda yang dapat merugikan perusahaan. Fenomena itulah yang menyebabkan banyak perusahaan melakukan penghindaran pajak (tax avoidance) agar perusahaan tetap membayar pajak tetapi dengan meminimalisir beban pajak yang akan dibayarkan.

Tindakan yang dilakukan perusahaan dalam meminimalkan beban pajak dapat berupa tindakan yang legal (tax avoidance) maupun ilegal (tax evasion). 
Perusahaan akan berusaha mengatur pembayaran pajak serendah-rendahnya agar dapat meningkatkan penghasilan yang didapat (Darmawan dan Sukartha, 2014). Penghindaran pajak (tax avoidance) adalah salah satu cara untuk menghindari pajak secara legal yang tidak melanggar peraturan perpajakan. Tax avoidance yang dilakukan ini dikatakan tidak bertentangan dengan peraturan undang-undang perpajakan karena dianggap praktik yang berhubungan dengan tax avoidance ini lebih memanfaatkan celah (loopholes) yang terdapat dalam peraturan perpajakan untuk menghindari pembayaran pajak yang jumlahnya lebih besar. Tax avoidance (penghindaran pajak) merupakan upaya untuk mengurangi hutang pajak yang bersifat legal dan aman bagi wajib pajak, tetapi tindakan ini dapatmenimbulkan resiko bagi perusahaan antara lain sanksi, denda dan buruknya reputasi perusahaan dimata publik. Namun ada perbedaan antara penghindaran pajak dengan penggelapan pajak yaitu tax evasion (penggelapan pajak) merupakan perilaku ilegal karena melanggar undang-undang atau peraturan yang berlaku. Pada umumnya perusahaan selalu ingin memaksimalkan labanya. Salah satu cara memaksimalkan laba yaitu dengan cara menghindari bayar pajak. Penghindaran pajak (tax avoidance) ini dilakukan dengan cara memanfaatkan celah hukum sehingga perusahaan tidak membayar pajak atau membayar pajak tetapi dengan beban pajak yang sangat kecil.

Tindakan penghindaran pajak dengan cara memperkecil beban pajak perusahaan merupakan salah satu penyebab tidak tercapainya target penerimaan pajak di Indonesia. Berdasarkan data target dan realisasi penerimaan pajak yang dipublikasikan pada Laporan Kinerja Direktorat Jenderal Pajak (DJP), besarnya 
Ni Putu Winda Ayuningtyas dan I Ketut Sujana. Pengaruh...

target dan realisasi penerimaan pajak pada Tahun 2014-2017, disajikan dalam Tabel 1 berikut.

Tabel 1.

Target dan RealisasiPenerimaan Pajak Tahun 2014-2017 (dalam Triliun Rupiah)

\begin{tabular}{lcccc}
\hline \multicolumn{1}{c}{ Tahun } & $\mathbf{2 0 1 4}$ & $\mathbf{2 0 1 5}$ & $\mathbf{2 0 1 6}$ & $\mathbf{2 0 1 7}$ \\
\hline Target Pajak & Rp 1.072,37 & Rp 1.294,26 & Rp 1.355,20 & Rp 1.283,56 \\
$\begin{array}{l}\text { Realisasi Pajak } \\
\text { Persentase Penerimaan }\end{array}$ & Rp 981,83 & Rp 1.060,83 & Rp 1.105,81 & Rp 1.151,13 \\
Pajak & $91,56 \%$ & $81,96 \%$ & $81,60 \%$ & $89,68 \%$ \\
\hline
\end{tabular}

Sumber: Menu Kinerja Penerimaan Portal Direktorat Jenderal Pajak, 2018

Tabel 1 menunjukkan bahwa realisasi penerimaan negara yang bersumber dari pajak di Indonesia belum mencapai target yang telah ditentukan dan selalu mengalami fluktuasi. Persentase capaian penerimaan pajak dari tahun 2014 ke tahun 2015 mengalami penurunan yang sangat signifikan sebesar 9,6\%, kemudian dari tahun 2015 ke tahun 2016 kembali mengalami penurunan sebesar 0,36\% dan terakhir dari tahun 2016 ke tahun 2017 persentase penerimaan pajak mulai mengalami peningkatan sebesar $8,08 \%$, tetapi walaupun mengalami peningkatan penerimaan, realisasi penerimaan pajak belum mencapai target yang diharapkan. Menurut Laporan Kinerja Direktorat Jenderal Pajak (2016), penurunan persentase penerimaan pajak ini disebabkan oleh salah satunya penurunan $\mathrm{PPh}$ pasal 25/29 Badan yang tercermin dari penurunan semua jenis setoran yaitu salah satunya setoran Tahunan $(-23,13 \%)$, STP $(-38,42 \%)$, dan SKPKB $(-29,49 \%)$. Fenomena penurunan penyetoran tersebut mungkin disebabkan oleh salah satunya perusahaan yang berusaha melakukan penghindaran pajak. Pada laporan Analisa Anggaran Pelaksanaan APBN yang dipublikasikan oleh websiteDewan Perwakilan Rakyat Republik Indonesia (2013) juga menyatakan bahwa tidak tercapainya target penerimaan Negara dikarenakan adanya penurunan tarif pajak, 
pemberian intensif pajak yang tidak tepat sasaran, rendahnya kesadaran masyarakat dalam membayar pajak, tingginya praktik penghindaran pajak (tax avoidance) dan penggelapan pajak (tax evasion) oleh wajib pajak badan dan pribadi, rendahnya integritas para pegawai pajak dan adanya tekanan dari ekonomi global.

Fenomena tax avoidance juga dapat dilihat dari beberapa perusahaan manufaktur dalam penelitian ini yang menerima SKPKB. DJP dapat menerbitkan SKPKB apabila hasil pemeriksaan pajak ditemukan pajak terutang kurang bayar oleh perusahaan. Beberapa perusahaan manufaktur yang mendapat SKPKB yang diterbitkan tahun 2017 dapat dilihat pada Tabel 2 berikut.

Tabel 2.

Perusahaan Manufaktur yang menerima SKPKB Tahun 2017

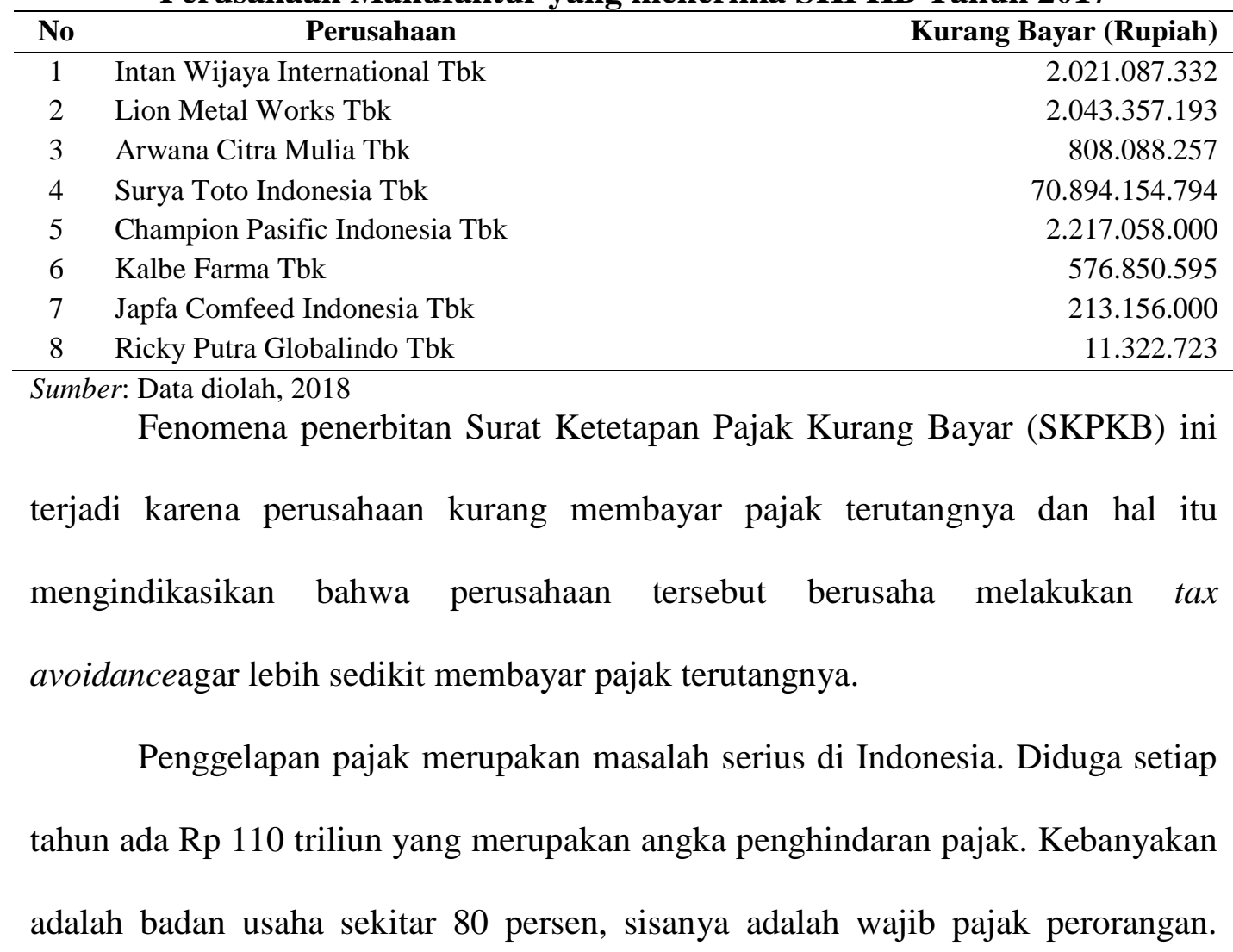


Ni Putu Winda Ayuningtyas dan I Ketut Sujana. Pengaruh...

Badan usaha yang melakukan penghindaran pajak kebanyakan yang bergerak disektor mineral dan batubara, kemudian perusahaan asing, serta ada juga perusahaan berbadan hukum Indonesia, tetapi kepemilikannya sebetulnya oleh asing (Sucipto, 2017). Di Indonesia sendiri, permasalahan mengenai praktik penghindaran pajak ini sudah sangat sering terjadi. Hasil studi Global Financial Integrity (GFI, 2017) mencatat aliran dana haram atau illicit yang dihasilkan dari penghindaran pajak dan aktivitas ilegal di Indonesia dan dikirim ke luar negeri mencapai US\$180,71 miliar dalam kurun 2004-2013. Dalam laporan GFI tersebut, Indonesia merupakan negara terbesar kesembilan di dunia sebagai negara asal dana illicit di seluruh dunia pada tahun 2017. Salah satu praktik ilegalillicit financial flows adalah penghindaran pajak dan pelarian pajak melalui transfer pricing. Hal tersebut dicurigai karena ditemukan sekitar 4.000 perusahaan multinasional yang beroperasi selama belasan dan puluhan tahun, terus melaporkan kerugian tapi tetap berekspansi. Transfer pricing dapat juga diartikan sebagai penetapan harga atas transaksi penyerahan barang berwujud, barang tidak berwujud, atau penyediaan jasa antar pihak yang memiliki hubungan istimewa atau transaksi afiliasi. Hal tersebut dapat disimpulkan bahwa transfer pricing adalah hal yang wajar dalam dunia usaha. Namun, dalam pengertian umum ditemukan di media, transfer pricing kemudian digunakan sebagai suatu praktik bisnis yang tidak baik, yaitu pengalihan atas penghasilan kena pajak (taxable income) dari suatu perusahaan yang dimiliki oleh perusahaan multinasional ke negara-negara yang tarif pajaknya rendah dalam rangka untuk mengurangi total beban pajak (Dinah, 2017). 
Penghindaran pajak yang dilakukan oleh perusahaan tentu saja tidak terlepas dari pengaruh pimpinan-pimpinan perusahaan tersebut yang sangat berperan dalam pengambilan keputusan perusahaan, Chief Executive Officer (CEO) dapat memengaruhi keputusan penghindaran pajak dengan mengatur "tone at the top" berkaitan dengan kegiatan pajak perusahaan (Dyreng et al., 2010). Selain Chief Executive Officer (CEO) terdapat pimpinan lainnya yaitu Komisaris Internal dan Komisaris Independen. Karakteristik corporate governance yang harus dimiliki perusahaan adalah komisaris independen yang berfungsi untuk melaksanakan pengawasan, mendukung pengelolaan perusahaan yang baik dan membuat laporan keuangan lebih objektif (Kurniasih dan Sari, 2013). Keputusan yang diambil oleh manajemen perusahaan akan dipengaruhi oleh keberadaan proporsi komisaris independen dalam perusahaan, termasuk keputusan yang terkait dengan pembayaran pajak yang diharapkan dapat meminimalisir kecurangan yang dapat terjadi. Komisaris independen menjadi penengah antara manajemen perusahaan dan pemilik perusahaan dalam mengambil kebijakan agar tidak melanggar hukum termasuk penentuan strategi yang terkait dengan pembayaran pajak (Putra danMerkusiwati, 2016).

Keberadaan komisaris independen dalam suatu perusahaan sangat berpengaruh pada kinerja perusahaan dan nilai perusahaan (Ying, 2011). Komisaris independen dalam perusahaan dapat memberikan arahan kepada manajer perusahaan untuk mengelola perusahaan dan merumuskan strategi yang dapat dilakukan perusahaan agar lebih baik termasuk dalam menentukan kebijakan mengenai pembayaran pajak yang akan dilakukan perusahaan. Menurut 
Ni Putu Winda Ayuningtyas dan I Ketut Sujana. Pengaruh...

Armstrong (2015), Dewan Komisaris yang lebih canggih dalam finansial atau keuangan khususnya Komisaris Independen dapat mengurangi masalah keagenan terkait dengan penghindaran pajak yang ekstrim.

Selain faktor Proporsi Komisaris Independen, faktor lain yang mempengaruhi perusahaan dalam melakukan aktivitas tax avoidance adalah Leverage atau tingkat hutang. Leverage adalah rasio hutang perusahaan yang digunakan pembiayaan kegiatan operasional perusahaan. Leverage merupakan penambahan jumlah utang yang mengakibatkan timbulnya pos biaya tambahan berupa bunga atau interest dan menyebabkan pengurangan beban pajak penghasilan WP Badan (Kurniasih dan Sari, 2013). Perusahaan manufaktur memanfaatkan utang untuk meminimalkan beban pajak perusahaan dalam hal melakukan penghindaran pajak. Hal ini dikarenakan perusahaan yang memiliki utang tinggi pasti akan memiliki beban bunga yang sangat tinggi pula. Beban bunga tersebut akan mengurangi penghasilan bersih perusahaan sehingga PKP perusahaan akan menjadi lebih rendah. Dengan menambah utang guna memperoleh keuntungan maka dapat dikatakan bahwa leverage mempengaruhi perusahaan melakukan tindakan tax avoidance (Suyanto dan Supramono, 2012).

Selain faktor-faktor tersebut, terdapat faktor sales growth dan profitabilitas yang juga mempengaruhi perusahaan untuk melakukan penghindaran pajak. Sales Growth (pertumbuhan penjualan) dapat diartikan sebagai kenaikan jumlah penjualan dari waktu ke waktu atau dari tahun ke tahun (Kennedy dkk., 2013), Sales Growth merupakan aktivitas yang memiliki peranan penting dalam manajemen modal kerja, hal tersebut disebabkan karena perusahaan dapat 
memprediksi seberapa besar profit yang akan diperoleh dengan besarnya sales growth. Peningkatan sales growth cenderung akan membuat perusahaan mendapatkan profit yang besar, maka dari itu sales growth dapat mempengaruhi perusahaan untuk melakukan praktik tax avoidance.

Profitabilitas merupakan gambaran kinerja keuangan perusahaan dalam menghasilkan laba dari pengelolaan aktiva yang dikenal dengan Retun On Assets (ROA). ROA memiliki keterkaitan dengan laba bersih perusahaan dan pengenaan pajak penghasilan untuk perusahaan (Kurniasih dan Sari, 2013). Semakin tinggi profitabilitas perusahaan akan semakin tinggi pula laba bersih perusahaan yang dihasilkan. Profit yang tinggi akan mempengaruhi perusahaan melakukan tax avoidance, karena jika laba yang diperoleh perusahaan meningkat, maka jumlah pajak penghasilan juga akan meningkat. Perusahaan dengan laba yang tinggi akan mempengaruhi perusahaan melakukan tindakan tax avoidance.

Penelitian ini dilakukan pada perusahaan manufaktur yang terdaftar di Bursa Efek Indonesia (BEI) dari tahun 2014-2017. Alasan pemilihan perusahaan manufaktur sebagai objek penelitian karena perusahaan tersebut melakukan aktivitas usaha secara menyeluruh mulai dari pembelian bahan baku hingga menjadi barang jadi dan siap dijual ke pasaran sehingga dalam aktivitas usahanya sebagian besar terkait dengan aspek perpajakan. Perusahaan manufaktur yang terdaftar di BEI lebih banyak dibandingkan dengan perusahaan lain. Perusahaan manufaktur sebagai suatu perusahaan yang telah menjadi wajib pajak yang difokuskan dalam daftar pemeriksaan Direktorat Jenderal Pajak karena berpotensi menambah pendapatan negara setiap tahunnya (Mulyani, 2014). Perusahaan 
Ni Putu Winda Ayuningtyas dan I Ketut Sujana. Pengaruh...

manufaktur yang tergolong dalam industri pengolahan memberikan kontribusi tertinggi sebagai penyetor pajak dilihat dari per sektor usahanya dibandingkan sektor lainnya yaitu tahun 2016 sebesar USD 100,36 milyar dan sampai November tahun 2017 sebesar 114,67 milyar (Artikel Kementerian Perindustrian, 2017).

Perusahaan manufaktur sebagai wajib pajak sering difokuskan dalam pemeriksaan Direktorat Jenderal Pajak karena pada tahun 2005 terdapat 750 perusahaan Penanaman Modal Asing (PMA) yang ditengarai melakukan penghindaran pajak dengan melaporkan rugi dalam waktu lima tahun berturutturut dan tidak membayar pajak (Bappenas, 2005 dalam Prakosa, 2014). Berdasarkan data pajak yang di sampaikan oleh Dirjen Pajak pada tahun 2012 ada 4000 perusahaan PMA yang melaporkan nihil nilai pajaknya, perusahaan tersebut diketahui ada yang mengalami kerugian selama 7 tahun berturut-turut. Perusahaan tersebut umumnya bergerak pada sektor manufaktur dan pengolahan bahan baku (DJP, 2013 dalam Prakosa, 2014).

Proporsi komisaris independen yang besar dalam struktur dewan komisaris akan memberikan pengawasan yang lebih baik dan dapat membatasi peluangpeluang kecurangan pihak manajemen (Raharjo dan Daljono, 2014). Adanya komisaris independen dalam perusahaan juga dapat memberikan petunjuk dan arahan untuk mengelola perusahaan serta merumuskan strategi perusahaan yang lebih baik termasuk dalam menentukan kebijakan terkait tarif pajak efektif yang akan dibayarkan perusahaan. Komisaris Independen merupakan bagian dari Dewan Komisaris yang berasal dari pihak luar perusahaan atau pihak independen. 
Sesuai dengan Theory Of Planned Behaviour, semakin besar proporsi komisaris independen maka semakin besar pengaruhnya untuk melakukan pengawasan perilaku manajemen dalam melakukan tindakan tax avoidance. Ketika perusahaan mengetahui semakin banyak komisaris independen akan semakin tinggi melakukan pengawasan, maka perusahaan akan mempertimbangkan perilaku dengan tidak melakukan tindakan tax avoidance.

Komisaris Independen ini sangat penting keberadaanya di perusahaan, karena komisaris ini dapat meminimalkan konflik kepentingan yang terjadi di dalam perusahaan yang melibatkan pihak agen dan principal dalam perusahaan tersebut. Selain itu keberadaan Komisaris Independen juga dapat menjalankan fungsi sebagai pengawas bagi komisaris internal dalam perusahaan tersebut, maupun sebagai pengawas bagi operasional perusahaan tersebut bagaimana perusahaan dijalankan apakah sesuai dengan standar dan peraturan atau tidak.

Menurut Rachmithasari (2015) jika komisaris independen bertambah maka penghindaran pajak akan mengalami penurunan. Hasil tersebut menunjukkan bahwa komisaris independen yang merupakan bagian dari dewan komisaris melakukan fungsi pengawasan yang cukup baik terhadap manajemen perusahaan. Hasil yang negatif menunjukkan bahwa keberadaan peningkatan komisaris independen dapat mencegah terjadinya penghindaran pajak. Penelitian lainnya juga dilakukan oleh Diantari dan Ulupui (2016). Menurut Diantari dan Ulupui (2016) Proporsi komisaris independen berpengaruh negatif terhadap tax avoidance. Hasil yang negatif, berarti jika proporsi komisaris independen 
Ni Putu Winda Ayuningtyas dan I Ketut Sujana. Pengaruh...

mengalami peningkatan maka akan terjadi penurunan tingkat tax avoidanc eTurunnya tingkat tax avoidance mengindikasikan perusahaan mampu membayar pajak dan CETR pun akan meningkat. Keberadaan komisaris independen efektif dalam usaha mencegah praktik tax avoidance. Menurut peraturan Otoritas Jasa Keuangan Nomor 33/POJK.04/2014 tentang Direksi dan Dewan Komisaris Emiten atau Perusahaan Publik menyatakan bahwa jumlah komisaris independen wajib paling kurang 30\% (tiga puluh persen)dari jumlah seluruh anggota dewan komisaris. Apabila presentase komisaris independen diatas 30\% maka ini merupakan satu indikator bahwa pelaksanaan corporate governance $(\mathrm{CG})$ telah berjalan dengan baik sehingga mampu mengontrol dan mengendalikan keinginan pihak manajemen perusahaan untuk melakukan penghematan pajak, menurunkan biaya keagenan sehingga membuat praktik tax avoidance menurun.

Secara logika, semakin banyak proporsi komisaris independen yang melakukan pengawasan di dalam perusahaan, makasemakin besar pengaruhnya dalam mengontrol perilaku manajemen dalam melakukan tindakan tax avoidance. Tingginya pengawasan yang dilakukan komisaris independen, dapat menekan sikap oportunistik manajemen terhadap bonus. Semakin banyak proporsi komisaris independen yang mengontrol kewajiban perusahaan dalam membayar pajak akan tercermin dari CETR perusahaan yang tinggi, sehingga menggambarkan tindakan tax avoidance perusahaan yang rendah.

$\mathrm{H}_{1}$ : Proporsi Komisaris Independen berpengaruh negatif pada Tax Avoidance

Leveragedapat menggambarkan struktur modal yang dimiliki oleh perusahaan. Dalam penelitian ini menggunakan proksi DER (Debt to Equity 
Ratio) yaitu perbandingan antara utang dengan modal dalam pendanaan kegiatan operasional perusahaan. Rasio DER dapat menunjukkan kemampuan modal perusahaan untuk memenuhi seluruh utangnya. Perusahaan selalu membutuhkan struktur modal yang baik untuk mengembangkan perusahaan dan untuk membiayai kegiatan operasional perusahaan. Struktur modal adalah pendanaan perusahaan yang salah satunya ditunjukkan oleh hutang.

Menurut Suyanto dan Supramono (2012), perusahaan manufaktur memanfaatkan utang untuk meminimalkan beban pajak perusahaan bahkan cenderung positif mengarah pada penghindaran terhadap pajak. Hal ini dikarenakan perusahaan yang memiliki utang tinggi pasti akan memiliki beban bunga yang sangat tinggi pula. Beban bunga tersebut akan mengurangi penghasilan bersih perusahaan sehingga PKP perusahaan akan menjadi lebih rendah. Hal tersebut sesuai dengan ketentuan Pasal 6 ayat (1) huruf a UU Nomor 36 tahun 2008, yang mengatakan bahwa besarnya penghasilan kena pajak bagi Wajib Pajak dalam negeri dan bentuk usaha tetap, ditentukan berdasarkan penghasilan bruto dikurangi biaya yang berkaitan dengan kegiatan usaha termasuk salah satunya yaitu biaya bunga. Hal ini juga sesuai dengan teori trade off, yang mengatakan bahwa perusahaan akan memanfaatkanutang untuk memaksimalkan nilai perusahaan karena utang akan menimbulkan beban bunga yang dimana beban bunga termasuk kedalam beban yang dapat mengurangi penghasilan kena pajak, sehingga perusahaan akan lebih sedikit membayar pajaknya. Selain itu UU Nomor 36 tahun 2008 pasal 23 ayat (4) menunjukkan bahwa pemotongan pajak tidak dilakukan atas salah satunya yaitu penghasilan yang dibayar atau terutang 
Ni Putu Winda Ayuningtyas dan I Ketut Sujana. Pengaruh...

kepada bank. Perusahaan manufaktur juga bisa memanfaatkan peraturan tersebut dengan berhutang kepada bank supaya penghasilan perusahaan tidak terkena potongan pajak. Hal tersebut bisa digunakan perusahaan untuk memanfaatkan celah-celah kecil untuk menghindari pajaknya. Sesuai dengan Theory Of Planned Behaviour, ketika manajer yakin akan adanya hasil yang menguntungkan dari memanfaatkan hutang yang tinggi untuk mengurangi beban pajak, perusahaan akan melakukan perilaku kecurangan dengan melakukan tax avoidance.

Penelitian terkait dengan leverage pernah dilakukan Koming Ayu Praditasari dan Ery Setiawan (2017), yang mengatakan bahwaleverage berpengaruh positif pada tax avoidance. Hal ini dapat terjadi karena beban bunga ditimbulkan akibat penggunaan utang dimana beban bungan termasuk ke dalam beban yang yang dapat mengurangi penghasilan kena pajak (deductible expense) sehingga penggunaan utang akan memberikan hubungan positif terhadap aktivitas tax avoidance oleh suatu perusahaan.Penelitian lainnya terkait leverage juga pernah dilakukan Rachmitasari (2015) yang menyatakan bahwa semakin tinggi nilai dari rasio leverage, berarti semakin tinggi jumlah pendanaan dari utang pihak ketiga yang digunakan perusahaan dan semakin tinggi pula biaya bunga yang timbul dari utang tersebut. Biaya bunga yang semakin tinggi akan memberikan pengaruh berkurangnya beban pajak perusahaan. Semakin tinggi nilai utang perusahaan maka nilai CETR perusahaan akan semakin rendah. Nilai CETR yang rendah mengindikasikan adanya tax avoidance yang tinggi didalam suatu perusahaan. 
Secara logika, semakin tinggi tingkat leverage pada suatu perusahaan, artinya semakin banyak pula pembiayaan kegiatan operasional perusahaan yang berasal dari utang atau dana pihak ketiga. Perusahaan dengan tingkat leverage yang tinggi akan menimbulkan beban bunga yang tinggi dan diasumsikan bahwa perusahaan menggunakan utang untuk meminimalkan beban pajak.Biaya bunga termasuk biaya yang dapat mengurangi penghasilan kena pajak yang sesuai dengan UU No. 36 tahun 2008 Ps 6 ayat (1), sehingga jika perusahaan memiliki beban bunga yang banyak maka perusahaan dapat lebih sedikit membayar beban pajaknya. Perusahaan yang sedikit membayar beban pajaknya akan tercermin dari CETR perusahaan yang rendah sehingga menggambarkan tax avoidance perusahaan yang tinggi.

$\mathrm{H}_{2}$ : Leverage berpengaruh positif pada Tax Avoidance.

Perusahaan dapat memprediksi seberapa besar profit yang akan diperoleh dengan besarnya pertumbuhan penjuralan (Sales Growth). Menurut Perdana (2013), pertumbuhan penjualan pada suatu perusahaan menunjukkan bahwa semakin besar volume penjualan maka laba yang akan dihasilkan pun akan meningkat. Pertumbuhan yang meningkat memungkinkan perusahaan akan lebih dapat meningkatkan kapasitas operasi perusahaan karena dengan pertumbuhan penjualan yang meningkat, perusahaan akan memperoleh profit yang meningkat pula. Perusahaan yang memiliki profit yang tinggi dianggap mampu membayar beban pajaknya sehingga dapat diasumsikan bahwa perusahaan mengarah negatif melakukan tindakan tax avoidance.Sesuai dengan Theory Of Planned Behaviour, ketika perusahaan mengetahui dengan pertumbuhan penjualan yang tinggi, akan 
Ni Putu Winda Ayuningtyas dan I Ketut Sujana. Pengaruh...

mendapatkan profit atau laba yang besar, maka perusahaan akan merencanakan perilaku yang taat dan patuh membayar pajak karena perusahaan dianggap mampu secara finansial membayar beban pajaknya dan untuk menghindari sanksi atau denda yang justru akan merugikan perusahaan.

Menurut penelitian yang dilakukan olehPuspita dan Febrianti (2017), sales growth berpengaruh negatif pada tax avoidance. Semakin tinggi pertumbuhan penjualan perusahaan maka besar kemungkinan laba yang dihasilkan perusahaan menjadi besar. Apabila laba yang dihasilkan perusahaan adalah besar, maka perusahaan akan mampu membayar pajaknya. Oleh karena itu, kemungkinan perusahaan untuk melakukan tindakan penghindaran pajak akan menjadi rendah. Kemudian penelitian lainnya dilakukan oleh Hidayat (2018), yang menyatakan bahwa sales growth berpengaruh negatif pada tax avoidance yang artinya semakin tinggi pertumbuhan penjualan, maka semakin berkurang aktivitas tax avoidance suatu perusahaan yang disebabkan karena perusahaan dengan tingkat penjualan yang relatif besar akan memberikan peluang untuk memperoleh laba yang besar dan mampu untuk melakukan pembayaran pajak.

Semakin tinggi tingkat sales growth atau pertumbuhan penjualanpada perusahaan, maka perusahaan dianggap mampu mengelola penjualannya sehingga perusahaan mendapatkan laba yang tinggi. Perusahaan yang memiliki laba tinggi pasti akan memiliki kas yang tinggi sehingga akan mampu secara finansial membayar beban pajak terutangnya. Perusahaan yang mampu membayar pajak akan meningkatkan nilai CETR perusahaan yang berarti tindakan tax avoidance menurun di dalam perusahaan. 
$\mathrm{H}_{3}$ :Sales Growth berpengaruh negatif pada Tax Avoidance.

Profitabilitas adalah suatu ukuran dalam menilai kinerja suatu perusahaan.

Profitabilitas merupakan gambaran kinerja keuangan perusahaan dalam menghasilkan laba dari pengelolaan aktiva yang dikenal dengan Retun On Assets (ROA). ROA memiliki keterkaitan dengan laba bersih perusahaan dan pengenaan pajak penghasilan untuk perusahaan (Kurniasih dan Sari, 2013). Rasio ROA disoroti dalam laporan keuangan karena dapat menunjukkan keberhasilan perusahaan dalam menghasilkan laba. Perusahaan yang mampu mengelola asetnya dengan baik maka perusahaan tersebut akan mendapatkan profit yang tinggi. Perusahaan yang memiliki profit yang tinggi dianggap mampu membayar beban pajaknya sehingga akan mengurangi tindakan tax avoidance dalam perusahaan.

Sesuai dengan Theory Of Planned Behaviour, ketika perusahaan memiliki profitabilitas yang tinggi, maka perusahaan akan merencanakan perilaku yang taat dan patuh membayar pajak karena perusahaan dengan profit yang tinggi dianggap mampu membayar beban pajaknya sehingga akan mengarah negatif pada tindakan tax avoidance.

Penelitian terkait pernah dilakukan oleh Arianandini dan Ramantha (2018) dan Utari dan Supadmi (2017), yangmenyatakan bahwa profitabilitas berpengaruh negatif pada tax avoidance. Semakin tinggi nilai ROA menyebabkan performa perusahaan semakin bagus. Perusahaan dengan nilai profitabilitas yang bagus diasumsikan tidak melakukan tax avoidance karena pertimbangan citra perusahaan akan menjadi buruk apabila perusahaan melalukan praktik tersebut. 
Ni Putu Winda Ayuningtyas dan I Ketut Sujana. Pengaruh...

Secara logika, semakin tinggi nilai ROA, maka semakin bagus pengelolaan aktiva didalam perusahaan dan berpotensi meningkatkan profit perusahaan. Perusahaan yang memiliki profit yang tinggi maka akan mampu membayar beban pajaknya karena dianggap tidak mengganggu modal kerja perusahaan pada saat membayar pajak. Pembayaran pajak yang tinggi akan tercermin dari CETR perusahaan yang tinggi dan menggambarkan tindakan tax avoidance yang rendah.

$\mathrm{H}_{4}$ :Profitabilitas berpengaruh negatif pada Tax Avoidance.

\section{METODE PENELITIAN}

Penelitian ini dilakukan di perusahaan manufaktur yang terdaftar di Bursa Efek Indonesia (BEI) periode tahun 2014-2017 dengan mengakses data perusahaan berupa informasi laporan keuangan pada situs resminya di www.idx.co.id dan mengakses daftar perusahaan melalui www.sahamok.com.

Objek penelitian pada penelitian ini adalah Proporsi Komisaris Independen $\left(\mathrm{X}_{1}\right)$, Leverage $\left(\mathrm{X}_{2}\right)$,Sales Growth $\left(\mathrm{X}_{3}\right)$, Profitabilitas $\left(\mathrm{X}_{4}\right)$, dan Tax Avoidance (Y). Perusahaan yang diteliti adalah perusahaan manufaktur yang terdaftar di Bursa Efek Indonesia periode 2014-2017.

Populasi penelitian pada seluruh perusahaan manufaktur yang terdaftar di BEI pada periode 2014-2017, karena perusahaan manufakturmerupakan perusahaan yang paling dominan terdaftar di BEI sehingga memudahkan dalam pengumpulan data serta perusahaan manufaktur juga berpotensi menjadi penyumbang pajak terbesar dan akan menambah pendapatan negara.Teknik sampling yang digunakan dalam penelitian ini adalah nonprobability sampling. 
Teknik analisis data yang digunakan dalam penelitian ini adalah teknik analisis regresi linier berganda. Penelitian ini bertujuan untuk menguji pengaruh proporsi komisaris independen, leverage, sales growth, dan profitabilitas pada tax avoidance yang dilakukan perusahaan.Adapun model regresi linier berganda menurt Utama (2016:77) dengan persamaan sebagai berikut.

$$
Y=\alpha+\beta_{1} X_{1}+\beta_{2} X_{2}+\beta_{3} X_{3}+\beta_{4} X_{4}+\varepsilon
$$

Keterangan :

$$
\begin{array}{ll}
\mathrm{Y} & =\text { Tax Avoidance } \\
\alpha & =\text { Nilai Konstanta } \\
\beta_{1} & =\text { Koefisien regresi Proporsi Komisaris Independen } \\
\beta_{2} & =\text { Koefisien regresi Leverage } \\
\beta_{3} & =\text { Koefisien regresi Sales Growth } \\
\beta_{4} & =\text { Koefisien regresi Profitabilitas (ROA) } \\
\mathrm{X}_{1} & =\text { Proporsi Komisaris Independen } \\
\mathrm{X}_{2} & =\text { Leverage } \\
\mathrm{X}_{3} & =\text { Sales Growth } \\
\mathrm{X}_{4} & =\text { Profitabilitas (ROA) } \\
\varepsilon & =\text { Error }
\end{array}
$$

Dari hasil analisis regresi akan diamati koefisien adjusted $\mathrm{R}$ square, uji kelayakan model (uji F) dan uji statistik t (uji t).

\section{HASIL DAN PEMBAHASAN}

Variabel yang diteliti dalam penelitian ini adalah tax avoidance, proporsi komisaris independen, leverage, sales growth, dan profitabilitas. Hasil uji statistik deskriptif disajikan dalam Tabel 3 berikut. 
Tabel 3.

Hasil Uji Statistik Deskriptif

\begin{tabular}{lrrrrr}
\hline & N & Minimum & Maximum & Mean & Std. Deviation \\
\hline CETR & 200 & 0,090 & 0,616 & 0,29155 & 0,089583 \\
PKI & 200 & 0,200 & 0,800 & 0,39708 & 0,091593 \\
DER & 200 & 0,077 & 5,395 & 0,81121 & 0,716546 \\
SG & 200 & $-0,299$ & 0,532 & 0,08025 & 0,115633 \\
ROA & 200 & 0,002 & 0,530 & 0,09809 & 0,080814 \\
Valid N (listwise) & 200 & & & & \\
\hline
\end{tabular}

Sumber: Data diolah, 2018

Berdasarkan tabel 3 dapat dijelaskan bahwa variabel terikat Tax Avoidance yang diproksikan melalui CETR memiliki nilai minimum sebesar 0,090 pada Mandom Indonesia Tbk di periode pengamatan 2015, sedangkan nilai maksimum sebesar 0,616 pada Lion Metal Works Tbk di periode pengamatan tahun 2017. CETR memiliki mean atau rata-rata sebesar 0,29155 dan hal ini menunjukkan bahwa nilai CETR yang tergolong tinggi dan mengindikasikan rendahnya tindakan tax avoidance didalam perusahaan. Nilai standar deviasi 0,089583 yang berarti adanya penyimpangan data terhadap nilai rata-ratanya sebesar 0,089583 dan menunjukkan hasil penyebaran data yang normal dan tidak menyebabkan bias.

Variabel bebas Proporsi Komisaris Independen (PKI) menunjukkan nilai minimum sebesar 0,200 pada Kimia Farma Tbk di periode pengamatan tahun 2016 dan 2017, serta Semen Baturaja Persero Tbk yaitu sebesar 0,200 pada tahun 2017. Perusahaan dengan Proporsi Komisaris Independen maksimum adalah Jembo Cable Company Tbk yaitu sebesar 0,800 pada periode pengamatan tahun 2016 dan 2017. Variabel Proporsi Komisaris Independen memiliki rata-rata (mean) sebesar 0,39708, hal ini menunjukkan bahwa perusahaan telah memenuhi ketentuan proporsi komisaris independen yang harus berjumlah minimal $30 \%$ atau 
0,3 dari total anggota dewan komisaris. Nilai standar deviasi 0,091593 yang berarti adanya penyimpangan data terhadap nilai rata-ratanya sebesar 0,091593 dan menunjukkan hasil penyebaran data yang normal dan tidak menyebabkan bias.

Variabel Leverage yang diproksikan dengan DER memiliki nilai minimum sebesar 0,077 pada Semen Baturaja Persero Tbk di tahun 2014. Perusahaan dengan Leverage maksimum adalah Jembo Cable Company Tbk yaitu sebesar 5,395 padatahun 2014. Variabel leverage memiliki mean atau rata-rata sebesar 0,81121, menunjukkan bahwa perusahaan banyak menggunakan tingkat hutang atau leverage untuk mendanai kegiatan operasional perusahaan. Nilai standar deviasi 0,716546 yang berarti adanya penyimpangan data terhadap nilai rata-ratanya sebesar 0,716546 dan menunjukkan hasil penyebaran data yang normal dan tidak menyebabkan bias.

Variabel Sales Growth (SG) memiliki nilai sales growth minimum sebesar-0,299 pada Lionmesh Prima Tbk di periode pengamatan tahun 2015. Perusahaan dengan nilai sales growth maksimum adalah Intan Wijaya International Tbk yaitu sebesar 0,532 pada pengamatan tahun 2017. Variabel sales growth memiliki mean atau rata-rata sebesar 0,08025, hal ini menunjukkan bahwa sales growth perusahaan tergolong cukup tinggi. Nilai standar deviasi yaitu sebesar 0,115633 yang berarti adanya penyimpangan data terhadap nilai rataratanya sebesar 0,115633 .

Variabel Profitabilitas yang diproksikan dengan ROA memiliki nilai minimum 0,002 pada Jembo Cable Company Tbk di periode pengamatan tahun 
Ni Putu Winda Ayuningtyas dan I Ketut Sujana. Pengaruh...

2015, sedangkan perusahaan dengan nilai profitabilitas maksimum adalah Lionmesh Prima Tbk yaitu sebesar 0,530 pada pengamatan tahun 2014. Variabel profitabilitas memiliki mean atau nilai rata-rata sebesar 0,09809, hal ini berarti perusahaan memiliki nilai ROA $9,8 \%$ dan terbilang cukup tinggi untuk menghasilkan laba perusahaan. Nilai standar deviasi yaitu sebesar 0,080814 yang berarti adanya penyimpangan data terhadap nilai rata-ratanya sebesar 0,080814 dan menunjukkan hasil penyebaran data yang normal dan tidak menyebabkan bias.

Tabel 4.

Hasil Uji Statistik F (Uji F)

\begin{tabular}{llrrrrr}
\hline Model & & \multicolumn{2}{c}{ Sum of } & & \multicolumn{1}{c}{ Mean } \\
Squares & df & Square & F & Sig. \\
\hline 1 & Regression & 0,185 & 4 & 0,046 & 6,374 & $0,000^{\mathrm{a}}$ \\
& Residual & 1,412 & 195 & 0,007 & & \\
& Total & 1,597 & 199 & & & \\
\hline
\end{tabular}

Sumber: Data diolah, 2018

Berdasarkan Tabel 4 memperlihatkan hasil perhitungam $\mathrm{F}$ menunjukkan angka sebesar 6,374 dengan tingkat signifikansi 0,000 lebih kecil dari $\alpha=0,05$, sehingga dapat disimpulkan bahwa model ini layak digunakan dalam penelitian.

Tabel 5.

Hasil Koefisien Determinasi $\left(\mathbf{R}^{2}\right)$

\begin{tabular}{|c|c|c|c|c|c|c|}
\hline \multirow{2}{*}{\multicolumn{2}{|c|}{ Model }} & \multicolumn{2}{|c|}{$\begin{array}{l}\text { Unstandardized } \\
\text { Coefficients }\end{array}$} & \multirow{2}{*}{$\begin{array}{c}\text { Standardized } \\
\text { Coefficients } \\
\text { Beta }\end{array}$} & \multirow[b]{2}{*}{$\mathbf{t}$} & \multirow[b]{2}{*}{ Sig. } \\
\hline & & B & Std. Error & & & \\
\hline 1 & (Constant) & 0,321 & 0,028 & & 11,544 & 0,000 \\
\hline & PKI & $-0,035$ & 0,067 & $-0,036$ & $-0,527$ & 0,599 \\
\hline & DER & 0,025 & 0,009 & 0,200 & 2,819 & 0,005 \\
\hline & SG & $-0,120$ & 0,054 & $-0,155$ & $-2,242$ & 0,026 \\
\hline & ROA & $-0,265$ & 0,076 & $-0,239$ & $-3,479$ & 0,001 \\
\hline
\end{tabular}

Berdasarkan tabel 5, dapat disimpulkan bahwa nilai adjusted $R$ square sebesar 0,097 yang artinya 9,7 persen variasi dari variabel terikat, yaitu tax avoidance dipengaruhi oleh variasi dari variabel independen yaitu proporsi 
komisaris independen, leverage, sales growth dan profitabilitas, sedangkan sisanya 90,3 persen dipengaruhi oleh faktor-faktor lain yang tidak dimasukkan ke dalam model regresi.

Hasil analisis regresi linier berganda dalam penelitian ini disajikan dalam Tabel. 4 berikut.

Tabel 4.

\begin{tabular}{rrrrr}
\hline Model & R & R Square & Adjusted R Square & $\begin{array}{c}\text { Std. Error of the } \\
\text { Estimate }\end{array}$ \\
\hline 1 & $0,340^{\mathrm{a}}$ & 0,116 & 0,097 & 0,085104 \\
\hline
\end{tabular}

Sumber: Data diolah, 2018

\section{Hasil Analisis Regresi Linier Berganda}

$$
\begin{array}{r}
\mathrm{Y}=\alpha+\beta 1 \mathrm{PKI}+\beta 2 \mathrm{DER}+\beta 3 \mathrm{SG}+\beta 4 \mathrm{ROA}+\varepsilon \ldots \ldots \ldots \ldots \\
\mathrm{Y}=\alpha-0,035 \mathrm{PKI}+0,025 \mathrm{DER}-0,120 \mathrm{SG}-0,265 \mathrm{ROA}+\varepsilon
\end{array}
$$

Berdasarkan hasil uji statistik t pada Tabel 4 diketahui bahwa variabel proporsi komisaris independen $(\mathrm{PKI})$ menunjukkan $\mathrm{t}_{\text {hitung }}=-0,527$ dengan tingkat signifikansi sebesar 0,599. Nilai 0,599 memiliki nilai signifikansi lebih besar dari 0,05. Nilai 0,599 > 0,05 yang artinya hipotesis pertama ditolak, dimana hasil pengujian variabel proporsi komisaris independen adalah negatif tetapi tidak signifikan yang berart variabel proporsi komisaris independen tidak berpengaruh pada tax avoidance.

Berdasarkan hasil uji statistik t pada Tabel 4 diketahui bahwa variabel leverage yang diproksikan dengan DER menunjukkan $t_{\text {hitung }}=2,819$ dengan tingkat signifikansi sebesar 0,005. Nilai signifikansi lebih kecil dari $\alpha=0,05$ atau nilai $0,005<0,05$ maka Hipotesis kedua diterima, yang menunjukkan variabel leverage berpengaruh positif pada tax avoidance. 
Ni Putu Winda Ayuningtyas dan I Ketut Sujana. Pengaruh...

Berdasarkan hasil uji statistik t pada Tabel 4diketahui bahwa variabel sales growth $(\mathrm{SG})$ menunjukkan $t_{\text {hitung }}=-2,242$ dengan tingkat signifikansi sebesar 0,026. Nilai signifikansi lebih kecil dari $\alpha=0,05$ atau nilai $0,026<0,05$ maka Hipotesis ketiga diterima, yang menunjukkan variabel sales growth berpengaruh negatif pada tax avoidance.

Berdasarkan hasil uji statistik t pada Tabel 4 diketahui bahwa variabel profitabilitas yang diproksikan dengan ROA menunjukkan $t_{\text {hitung }}=-3,479$ dengan tingkat signifikansi sebesar 0,001. Nilai signifikansi lebih kecil dari $\alpha=0,05$ atau nilai 0,001 < 0,05 maka Hipotesis keempat diterima, yang menunjukkan variabel profitabilitas berpengaruh negatif pada tax avoidance.

\section{SIMPULAN}

Berdasarkan hasil analisis data dan pembahasan yang telah diuraikan maka dapat diambil kesimpulan bahwa proporsi komisaris independen tidak berpengaruh pada tax avoidance, yang artinyasemakin tinggi proporsi komisaris independen, maka semakin tidak efektif dalam mengontrol perusahaan memenuhi kewajiban perpajakannya yang tercermin dari CETR yang rendah sehingga menggambarkan tax avoidance yang tinggi.

Leverage berpengaruh positif pada tax avoidance, yang artinya semakin tinggi tingkat leverage pada suatu perusahaan, maka modal kerja perusahaan akan terganggu dan menyebabkan pembayaran pajak perusahaan menjadi kurang optimal. Pembayaran pajak yang rendah tercermin dari CETR yang rendah dan menggambarkan tax avoidance perusahaan yang tinggi. 
Sales Growth berpengaruh negatif pada tax avoidance, yang artinya semakin tinggi sales growth, maka semakin tinggi laba yang diperoleh perusahaan. Perusahaan yang memiliki laba yang tinggi memiliki modal kerja yang baik sehingga dianggap mampu membayar pajaknya yang tercermin dari CETR yang tinggi, menggambarkan tax avoidance yang rendah.

Profitabilitasberpengaruh negatif pada tax avoidance, yang artinya semakin tinggi nilai Return On Assets makaakan meningkatkan profit perusahaan. Perusahaan yang memiliki profit yang tinggi akan mampu memenuhi modal kerjanya dengan baik sehingga akan mampu membayar pajaknya yang tercermin dari CETR yang tinggi, menggambarkan tax avoidance perusahaan yang rendah.

Dari hasil menganalisis data dan pembahasan yang telah diuraikan maka bisa diambil kesimpulan bahwa proporsi komisaris independen tidak berpengaruh pada tax avoidance, yang artinyasemakin tinggi proporsi komisaris independen, maka tidak dapat mempengaruhi perusahaan dalam melakukan tindakan tax avoidance.

Leverage berpengaruh positif pada tax avoidance, yang artinya perusahaan memanfaatkan utang yang menimbulkan beban bunga untuk meminimalisir pembayaran pajak. Perusahaan yang sedikit membayar pajak akan tercermin dari nilai CETR yang rendah sehingga menggambarkan tax avoidance yang tinggi.

Sales Growth berpengaruh negatif pada tax avoidance, yang artinya semakin tinggi sales growth, maka semakin tinggi laba yang diperoleh perusahaan. Perusahaan yang memiliki laba yang tinggi memiliki modal kerja 
Ni Putu Winda Ayuningtyas dan I Ketut Sujana. Pengaruh...

yang baik sehingga dianggap mampu membayar pajaknya yang tercermin dari CETR yang tinggi, menggambarkan tax avoidance yang rendah.

Profitabilitas berpengaruh negatif pada tax avoidance, yang artinya semakin tinggi nilai Return On Assets makaakan meningkatkan profit perusahaan. Perusahaan yang memiliki profit yang tinggi akan mampu memenuhi modal kerjanya dengan baik sehingga akan mampu membayar pajaknya yang tercermin dari CETR yang tinggi, menggambarkan tax avoidance perusahaan yang rendah.

Daripembahasan hasil data dan simpulan yang telah dilakukan, saran yang dapat diajukan untuk penelitian selanjutnya dan untuk pihak-pihak yang berkepentingan adalah dalam penelitian ini hasil adjusted $\mathrm{R}^{2}$ yang diperoleh masih tergolong rendah yaitu 9,7 persen, hal ini menunjukkan bahwa 9,7 persen tax avoidance dipengaruhi oleh variabel independen yang digunakan dalam penelitian ini, sedangkan sisanya dipengaruhi oleh variabel lain. Bagi penelitian selanjutnya, dapat meneliti variabel lain yang dapat menyempurnakan penelitian iniseperti proksi good corporate governance yang menggunakan indeks CGPI dengan memberikan peringkat indeks terbaik diantara perusahaan yang menerapkan corporate governance. Perusahaan yang memiliki indeks corporate governance yang baik, cenderung akan mengurangi tindakan tax avoidance.

Sesuai dengan Theory of Planned Behaviour, ketika perusahaan memiliki kondisi modal kerja yang baik maka perusahaan akan memiliki niat untuk memenuhi kewajiban perpajakannya dan merencanakan perilaku yang patuh membayar pajak. Saran yang dapat diberikan yaitu, perusahaan dapat 
merencanakan niat dan perilaku yang memenuhi kewajiban perpajakannya sehingga dapat mengurangi perilaku penghindaran pajak (tax avoidance).

\section{REFERENSI}

Arianandini, P. W., \& Ramantha, I. W. (2018). Pengaruh Profitabilitas, Leverage, dan Kepemilikan Institusional pada Tax Avoidance. E-Jurnal Akuntansi Universitas Udayana, 22(3), 2088-2116.

Armstrong, C. S. (2015). Corporate Governance, Incentives, and Tax Avoidance, $0-42$.

Biro Analisa Anggaran dan Pelaksanaan APBN. 2013. Evaluasi Rendahnya Realisasi Pendapatan Negara Tahun 2013.

Darmawan, I. G. H., \& Sukartha, I. M. (2014). Pengaruh Penerapan Corporate Governance, Leverage, ROA dan Ukuran Perusahaan pada Penghindaran Pajak. E-Jurnal Akuntansi, 9(1), 143-161.

Diantari, P. R., \& Ulupui, A. I. (2016). Pengaruh Komite Audit, Proporsi Komisaris Independen, dan Proporsi Kepemilikan Institusional Terhadap Tax Avoidance. E-Jurnal Akuntansi Universitas Udayana, 16.1, 702-732.

Dinah, Aida Farah, D. (2017). Pengaruh Tata Kelola Perusahaan, Profitabilitas, Dan Penghindaran Pajak Terhadap Nilai Perusahaan, 6, 1-15.

Dyreng, S. D., Hanlon, M., \& Maydew, E. L. (2010). The Effects Of Executives On Corporate Tax Avoidance. Accounting Review, 85(4), 1163-1189. https://doi.org/10.2308/accr.2010.85.4.1163

Kementerian Keuangan Republik Indonesia. (2018). APBN Kita Edisi Januari. https://www.kemenkeu.go.id/media/6890/apbn-kita-edisi-januari-2018.pdf. Diakses 12 Juni 2018.

Kementerian Perindustrian Republik Indonesia. (2017). Lampaui 31 Persen, Industri Manufaktur Penyumbang Pajak Terbesar.

Kementerian Perindustrian Republik Indonesia. (2017). Sektor-Sektor Manufaktur Andalan Tahun 2018. http://www.kemenperin.go.id/artikel/18609/SektorSektor-Manufaktur-Andalan-Tahun-2018. Diakses 14 Juni 2018.

Kennedy, dkk. (2010). Faktor- faktor yang Mempengaruhi Struktur Modal pada Perusahaan Real Estate and Property yang Go Public Di Bursa Efek Indonesia. Jurnal. Universitas Riau. 
Ni Putu Winda Ayuningtyas dan I Ketut Sujana. Pengaruh...

Koming Ayu Praditasari, N., \& Ery Setiawan, P. (2017). Pengaruh Good Corporate Governance, Ukuran Perusahaan, Leverage Dan Profitabilitas Pada Tax Avoidance. E-Jurnal Akuntansi Universitas Udayana, 19, 12291258.

Kurniasih, T., \&Sari, M. M. R. (2013). Pengaruh Return On Assets, Leverage, Corporate Governance, Ukuran Perusahaan, dan Kompensasi Rugi Fiskal Terhadap Tax Avoidance. E-jurnal Akuntansi Universitas Udayana, 18 (1), hal 1-84

Lim, YD. (2011). Tax Avoidance, cost of debt and shareholder activism: Evidende from Korea. Journal of Banking \& Finance 35, 456-470.

Mulyani, S., Darminto., \& Endang, M.W. (2014). Pengaruh Karakteristik Perusahaan, Koneksi Politik dan Reformasi Perpajakan Terhadap Penghindaran Pajak (Studi pada perusahaan manufaktur yang terdaftar di BEI tahun 2008-2012). Jurnal Mahasiswa Perpajakan Universitas Brawijaya, Vol. 1, No. 2, 2014, hal 1-9.

Perdana,W. (2013). Pengaruh Rasio Likuiditas, Profitabilitas, dan, Pertumbuhan terhadap Harga Saham (Suatu Studi pada Perusahaan yang tergabung dalam Indeks LQ 45 yang Terdaftar di Bursa Efek Indonesia). Jurnal.http://digilib.unpas.ac.id/files/disk1/53/jbptunpaspp-gdl widiyanape -2620-2-babii.pdf. Diakses pada tanggal 30 Juni 2018.

Prakosa, Kesit Bambang. (2014). Pengaruh Profitabilitas, Kepemilikan Keluarga, dan Corporate Governance Terhadap Penghindaran Pajak di Indonesia. Simposium Nasional Akuntansi XVII. 22-27 September 2014. Mataram, Indonesia. Hal. 1-27.

Puspita Dewi, N. L. P., \& Noviari, N. (2017). Pengaruh Ukuran Perusahaan, Leverage, Profitabilitas Dan Corporate Social Responsibility Terhadap Penghindaran Pajak (Tax Avoidance) Fakultas Ekonomi dan Bisnis Universitas Udayana (Unud), Bali, Indonesia Fakultas Ekonomi dan Bisnis Universitas Uda, 21, 830-859.

Putra, I. G. L. N. D. C., \& Merkusiwati, N. K. L. A. (2016). Pengaruh Komisaris Independen, Leverage, Size dan Capital Intensity Ratio Pada Tax Avoidance. E-Jurnal Akuntansi Universitas Udayana, 17(1), 690-714.

Rachmithasari, A. F. (2015). Pengaruh Return On Assets, Leverage, Corporate Governance, Ukuran Perusahaan Dan Kompensasi Rugi Fiskal Pada Tax Avoidance. Jurnal UniversitasSurakarta. Fakultas Ekonomi Dan Bisnis, Universitas Muhammadiyah Surakarta.

Raharjo, A. S.,\& Daljono. (2014). Pengaruh Dewan Komisaris, Direksi, Komisaris Independen, Struktur Kepemilikan dan Indeks Corporate 
Governance Terhadap Asimetri Informasi. Diponegoro Journal of Accounting.3(3), 1-13.

Suyanto, K. D., \& Supramono. (2012). Likuiditas, Leverage , Komisaris Independen, dan Manajemen Laba Terhadap Agresivitas Pajak Perusahaan. Jurnal Keuangan dan Perbankan. Vol16(2), 167-177.

Utama, Made Suyana. (2016). Aplikasi Analisis Kuantitatif. Denpasar: CV. Sastra Utama.

Utari, N. K. Y., \& Supadmi, N. L. (2017). Pengaruh Corporate Governance, Profitabilitas Dan Koneksi Politik Pada Tax Avoidance. E-Jurnal Akuntansi Universitas Udayana, 18, 2202-2230.

Ying, Zing. (2011). Ownership Structure, Board Characteristics, and Tax Aggressivenes. Thesis of Linganan University. 